\title{
Markedly Reduced Activity of Lysyl Oxidase in Skin and Aorta from a Patient with Menkes' Disease Showing Unusually Severe Connective Tissue Manifestations ${ }^{1}$
}

\author{
PETER M. ROYCE AND BEAT STEINMANN \\ Division of Metabolism, Department of Paediatrics, University of Zürich Children's Hospital, CH-8032 \\ Zürich. Switzerland
}

\begin{abstract}
In Menkes' disease, a severe disturbance of copper handling appears to render copper unavailable for copper-requiring processes. We have measured the activity of lysyl oxidase, the copper-dependent enzyme that initiates the cross-linking of collagen and elastin, in extracts of skin and aorta obtained at autopsy from a patient with unusually marked connective tissue manifestations, and found it to be only $6-12 \%$ of normal, thus suggesting a basis for these alterations. (Pediatr Res 28: 137-141, 1990)
\end{abstract}

\section{Abbreviations}

EMEM, Eagle's minimum essential medium with Earle's salts, containing $10 \%$ (vol/vol) FCS

Menkes' disease (MIM 30940 in ref. 1) is an X-linked, recessively inherited disorder in which, although the precise nature of the basic defect remains unknown, disturbed copper handling appears to render copper unavailable to copper-requiring processes (2-4). It has an estimated frequency of 1 in 50000 to 100 000 live births (4) and, although a mild form of the disorder does appear to exist (5-7), and despite the longer survival of a small proportion of cases both with and without copper therapy $(4,8-$ 11 ), death usually occurs before 3 y of age, most frequently from respiratory infections such as pneumonia $(3,4)$. The disorder is characterized principally by growth retardation, progressive cerebral degeneration, distinctive facial features, hypopigmentation of skin and hair, a tendency to recurrent episodes of hypothermia, and abnormal hair $(3,4)$. There are also connective tissue alterations, which include bone changes reminiscent of those seen in scurvy, Wormian bones in the skull, and arterial abnormalities that may lead to thrombosis and rupture, although these features of the disorder are not usually the most prominent $(3,4)$.

Serum levels of copper and ceruloplasmin are greatly below normal, and although this was initially regarded simply as the result of intestinal malabsorption of copper $(12,13)$, Menkes' disease has proved to be extremely recalcitrant to parenteral copper therapy $(4,14)$. After the demonstration of a copper accumulation phenotype in cultured fibroblasts from patients

Received November 29, 1989; accepted March 9, 1990

Correspondence: Dr. P. M. Royce, Stoffwechselabteilung. Kinderspital, Steinwiesstrasse 75, CH-8032 Zürich. Switzerland.

Supported by Grants 3.905.083 and 3.905.086 from the Swiss National Science Foundation

'Presented in part at the 19th Annual Meeting of the Swiss Societies for Experimental Biology. Lausanne. Switzerland [Experientia 1987, 43:667(abstr)] and the Annual Meeting of the European Society for Pediatric Research, Padova, Italy [Pediatr Res 1987, 22:237(abstr)], both in 1987.
(15-17), the concept has arisen of a functional intracellular copper deficiency in which, despite even elevated levels of intracellular copper, copper is unavailable to copper-dependent enzymes $(2,4,14,18)$.

Most features of the disorder are explicable on the basis of impaired function of copper-dependent enzymes (4, 14, 18). Thus, the connective tissue abnormalities were logically proposed as being principally the result of deficient crosslink formation of collagen and elastin consequent upon decreased activity of lysyl oxidase $(13,19)$, the copper-dependent enzyme that functions to initiate the process through the oxidative deamination of the 6$\mathrm{NH}_{2}$ group of lysyl or hydroxylysyl residues within the nonhelical telopeptides of the collagen $\alpha$-chains, or of specific lysyl residues in elastin, to form the aldehydic precursors of the cross-links (20-22).

The activity of lysyl oxidase in cultures of fibroblasts derived from a number of patients with Menkes' disease has previously been reported to be reduced quite considerably $(19,23)$. We recently had the opportunity to study a patient with unusually severe connective tissue manifestations, and report here the first determinations of tissue lysyl oxidase activity in the disorder. In extracts of both skin and aorta obtained at autopsy, lysyl oxidase activity was drastically reduced to $6-14 \%$ of control values. Quite surprisingly, despite this, the solubility of collagen in the two tissues appeared to be no greater than normal. This finding is, nevertheless, in accord with ultrastructural evidence indicative of a far greater disruption of elastin than collagen (24, and Baccarani-Contri M, Pasquali-Ronchetti I, Royce PM, Steinmann B, unpublished observations).

\section{CASE REPORT}

A detailed case report has already appeared (25), the essential features of which are as follows. The patient was the 2 nd child of young, healthy, unrelated parents, who had previously had a clinically normal daughter. He was delivered normally at 37.5 wk, weighed $2.94 \mathrm{~kg}$, and was $51 \mathrm{~cm}$ in length. His skin was noted to be dry, with little s.c. fat, and lax over the whole body, particularly the hands and feet. An episode of hypothermia on the 2 nd day of life necessitated a 24-h spell in an incubator. On the 6 th day of life, it was noticed that both humeri and the right clavicle and second rib were fractured. Radiography of the right arm showed diminished bone density, and numerous Wormian bones were apparent in the skull. At about $10 \mathrm{wk}$ of age, he became apathetic and took his feed poorly, and shortly afterwards suffered convulsions, at first focal, and later generalized. He was taken into hospital, where he remained until his death at approximately $11 \mathrm{mo}$ of age. Serum copper was undetectable, and ceruloplasmin virtually undetectable. Cranial computerized tomography showed progressive cerebral atrophy and subdural 
hematomas. Scalp hairs were sparse and twisted. Additional indications of generalized connective tissue involvement were bladder diverticula and diffuse arterial anomalies consisting of an intimal hyperplasia associated with a duplication and fragmentation of the internal elastic lamina, particularly in the case of the aorta and coronary arteries. The cerebral arteries were markedly tortuous.

\section{MATERIALS AND METHODS}

Tissues and cells. Skin and aorta obtained at autopsy of the patient and controls were stored at $-70^{\circ} \mathrm{C}$ until used. Fibroblast cultures were established from skin biopsies of the patient and each of his parents by Prof. G. Pescia, Centre Hospitalier Universitaire Vaudois, Lausanne, Switzerland. Cultures were also established from skin biopsies of control subjects, and grown in EMEM. "Contrast" fibroblast lines from two patients with Menkes' disease were purchased, one each from the Human Genetic Mutant Cell Repository, Camden, NJ (cell line GM 1981) and the American Type Culture Collection, Rockville, MD (cell line CRL 1230).

Determination of copper content of tissues. Samples of skin and aorta were dried to constant weight and dissolved in concentrated $\mathrm{HNO}_{3}$ (Aristar grade; $\mathrm{BDH}$ Chemicals, Poole, England) (26). Copper in the solutions was measured using a Perkin-Elmer model 5000 atomic absorption spectrophotometer equipped with an HGA 500 programmable graphite furnace (Perkin-Elmer, Norwalk, CT).

Lysyl oxidase assay. Before extraction of lysyl oxidase, s.c. fat was scraped away from skin and aorta was cleaned of adherent tissue. Tissues were homogenized as previously described (27), except that only a single extraction with first PBS and then $4 \mathrm{M}$ urea/0.05 M Tris $\mathrm{HCl}$, pH 7.7 at $4^{\circ} \mathrm{C}$, was performed.

Fibroblasts were grown in $75 \mathrm{~cm}^{2}$ flasks in EMEM until they had just reached confluent density. The cell layers were washed twice with serum-free EMEM and then incubated in $5 \mathrm{~mL}$ of this medium supplemented with ascorbic acid $(50 \mu \mathrm{g} / \mathrm{mL})$ for 24 h. After this time, the medium was removed and stored at $-20^{\circ} \mathrm{C}$, while the cell layers were harvested by trypsinization. The cell pellets were washed 3 times with serum-free EMEM, then dissolved in sodium deoxycholate before protein determination, as previously described (19).

The activity of lysyl oxidase (protein-lysine 6-oxidase, EC 1.4.3.13) in $4 \mathrm{M}$ urea extracts of tissues and in serum-free fibroblast culture medium, both previously dialyzed against PBS, was determined using a tritium-release procedure (28) with an $\mathrm{L}-\left[4,5{ }^{3} \mathrm{H}\right]$ lysine-labeled fibrillar collagen substrate prepared from the calvariae of 16- to 17-d-old embryonic chicks, all as previously described $(19,27)$, except that the bones were labeled in lysine-free and serum-free EMEM and homogenized using a Polytron homogenizer (Kinematica, Kriens LU, Switzerland, and vials containing the reaction mixtures were not flushed with $\mathrm{O}_{2}$ beiore incubation. EDTA treatment of glassware and dialysis tubing and Chelex treatment of PBS were also omitted. Each reaction mixture used 800000 to $1000000 \mathrm{cpm}$ of substrate, and incubation was for $10 \mathrm{~h}$ at $37^{\circ} \mathrm{C}$.

Prolyl hydroxylase assay. The activity of prolyl hydroxylase (procollagen-proline, 2-oxoglutarate 4-dioxygenase, EC 1.14.11.2) in fibroblast extracts was determined using a tritium-release procedure, with an L-[4- $\left.{ }^{3} \mathrm{H}\right]$ proline-labeled protocollagen (unhydroxylated procollagen) substrate, as described previously $(29,30)$.

Extraction of collagen from tissue samples. Samples of skin and aorta were chopped finely with a scalpel and soaked in 0.5 $\mathrm{M}$ acetic acid ( $\mathrm{pH}$ adjusted to 2 with concentrated $\mathrm{HCl}$ ) at $4^{\circ} \mathrm{C}$ for approximately $2 \mathrm{~h}$. Portions of a freshly prepared pepsin stock solution were then added to the samples to give an approximate pepsin:tissue ratio of 1:100 and the samples were shaken at $4^{\circ} \mathrm{C}$ for $22 \mathrm{~h}$. Two sequential extracts were pooled and neutralized to inactivate the pepsin by the addition of Tris base to $50 \mathrm{mM}$ and then the addition of $5 \mathrm{M} \mathrm{NaOH}$ to $\mathrm{pH}$ 8. After standing the extracts for $24 \mathrm{~h}$, they were dialyzed exhaustively against $0.5 \mathrm{M}$ acetic acid, lyophilized, and subjected to SDSPAGE, as previously described (31).

Further samples of skin and aorta were cut finely with a scalpel, homogenized in $1 \mathrm{M} \mathrm{NaCl} / 0.05 \mathrm{M}$ Tris $\mathrm{HCl}, \mathrm{pH} 7.4$ at $4^{\circ} \mathrm{C}$ with a Polytron homogenizer ( 3 times for $15 \mathrm{~s}$ ), then extracted sequentially with this solution, $0.5 \mathrm{M}$ acetic acid, and $8 \mathrm{M}$ urea, for 24-h periods (23). The extracts were dialyzed exhaustively against $0.5 \mathrm{M}$ acetic acid, then both they and the insoluble residue were lyophilized and hydrolyzed in $6 \mathrm{M} \mathrm{HCl}$ at $110^{\circ} \mathrm{C}$ for $24 \mathrm{~h}$. Hydroxyproline in the hydrolysates was determined by automated amino acid analysis.

\section{RESULTS}

Copper incorporation studies with cultured fibroblasts. The combination of the patient's clinical symptoms and the virtual undetectability of serum copper and ceruloplasmin when investigated at about 6 mo of age was suggestive of Menkes' disease. The diagnosis was firmly established by the results of ${ }^{64} \mathrm{Cu}$ uptake studies on cultured fibroblasts (32), kindly performed by Dr. T. Tønnesen of the John F. Kennedy Institute, Glostrup, Denmark, which show (Table 1) that over a 20 -h period, the copper uptake of fibroblasts from the patient falls in the middle of the range for Menkes' patients. The results also show that although the father is normal, the mother is quite clearly heterozygous for the disorder.

Copper content of tissues. The copper content of both skin and aorta obtained from the patient at autopsy was increased, in the case of the former to about 1.5 times normal, and in that of the latter by $\sim 2$-fold (Table 2 ).

Lysyl oxidase activity in fibroblast cultures. It has been well established that in skin fibroblast cultures $90 \%$ or more of the total lysyl oxidase activity is present in the medium $(23,33$, and Royce PM, unpublished results). Consequently, lysyl oxidase activity was determined only in serum-free medium in which fibroblasts had been cultured. As detailed in Figure 1, activity in the medium of the patient's fibroblasts was only between 6 and $14 \%$ of that in the medium of control fibroblasts. Strikingly, it was also only between $1 / 3$ and $1 / 2$ that in the medium of fibroblast cultures derived from two other Menkes' patients.

Prolyl hydroxylase activity in fibroblast cultures. Prolyl 4hydroxylase is an intracellular enzyme that catalyses the hydroxylation of certain prolyl residues in collagen to form hydroxyprolyl residues, without which it could not adopt its triple helical conformation at physiologic temperature. No reduction in activity of this enzyme was observed in the patient's fibroblasts (sp act $180442 \mathrm{cpm} / 100 \mu \mathrm{g}$ cell layer protein) when compared with either control fibroblast lines $(n=4$; mean sp act $176995 \mathrm{cpm} /$ $100 \mu \mathrm{g}$ cell layer protein; range 137538 to $207810 \mathrm{cpm}$ ) or

Table 1. Incorporation of ${ }^{64} \mathrm{Cu}$ by cultured fibroblasts*

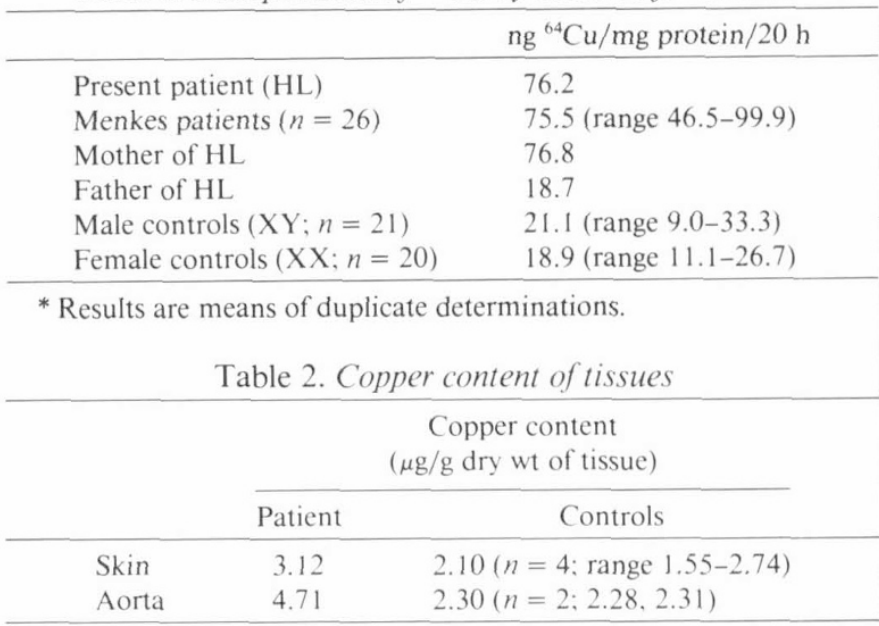




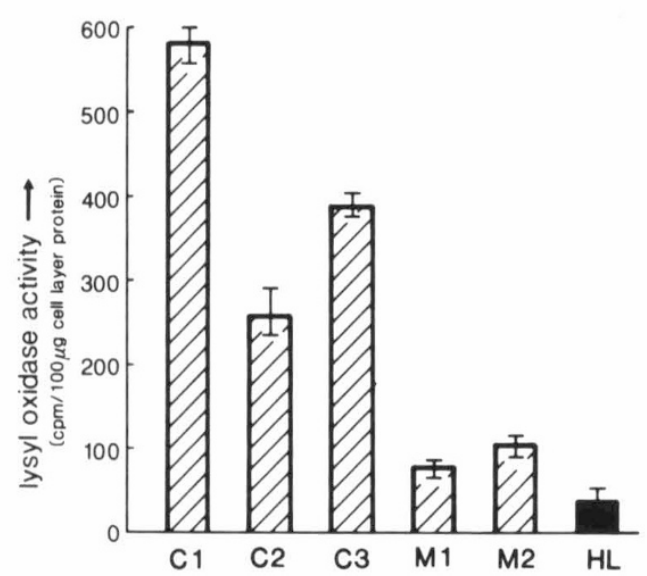

Fig. 1. Activity of lysyl oxidase in fibroblast cultures. C1, C2, C3, control lines; M1, M2, Menkes' contrast lines; HL, present patient. Activity in medium is expressed as $\mathrm{cpm}^{3} \mathrm{H}_{2} \mathrm{O}$ released from the substrate per $100 \mu \mathrm{g}$ cell layer protein. All assays were performed in duplicate, on cultures set up in triplicate, and the results are calculated from mean values, the range of which is shown by hars. The residual activity of HL, expressed as a percentage of that in the medium of cultures from controls and other Menkes' patients, was as follows: $\mathrm{HL}$ vs $\mathrm{C} 1,6.2 \%$; $\mathrm{HL}$ vs $\mathrm{C} 2$, 14.1\%; HL vs C3, 9.3\%; HL vs M1 (CRL 1230), 46.8\%; and HL vs M2 (GM1981), 34.3\%.

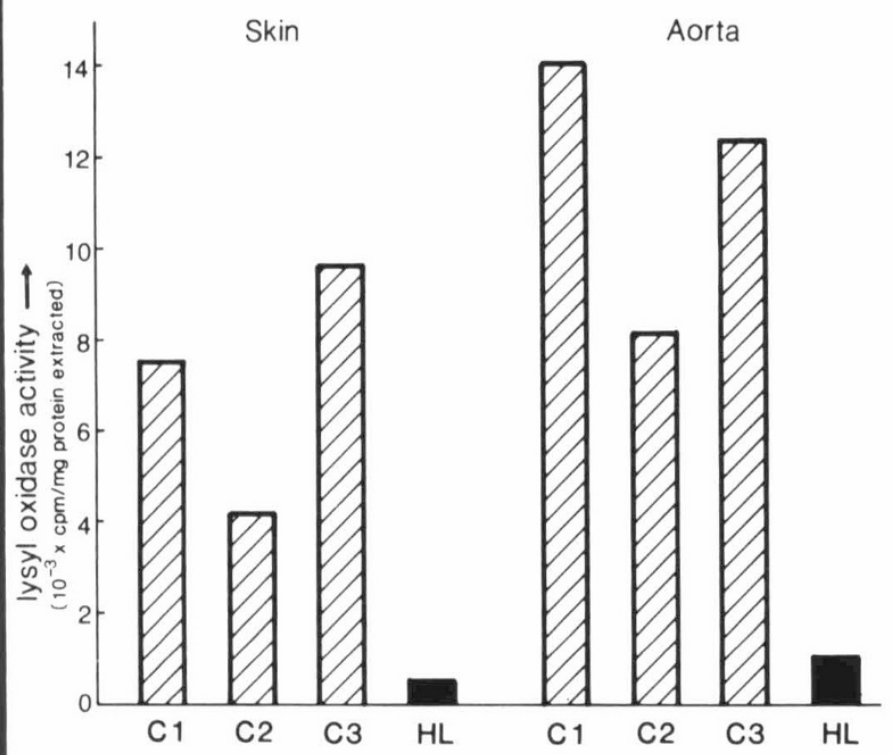

Fig. 2. Activity of lysyl oxidase in tissue extracts. C1, C2, C3, control tissues; HL, present patient. Activity in $4 \mathrm{M}$ urea extracts is expressed as cpm ${ }^{3} \mathrm{H}_{2} \mathrm{O}$ released from the substrate per $\mathrm{mg}$ is protein in the extract. Results are calculated from the mean values of duplicate determinations. The residual activity of HL, expressed as a percentage of that in comparable extracts of control tissues, was as follows. Skin: HL vs $\mathrm{C} 1,6.8 \%$; HL vs $\mathrm{C} 2,12.2 \%$; and $\mathrm{HL}$ vs $\mathrm{C} 3,5.4 \%$. Aorta: $\mathrm{HL}$ vs $\mathrm{C} 1,7.0 \%$; HL vs C2, $12.0 \%$; and $\mathrm{HL}$ vs $\mathrm{C} 3,7.9 \%$.

contrast Menkes' fibroblast lines $(n=2$; sp act 121718 and 158 $654 \mathrm{cpm} / 100 \mu \mathrm{g}$ cell layer protein).

Lysyl oxidase activity in tissue extracts. As shown in Figure 2, the activity of lysyl oxidase in $4 \mathrm{M}$ urea extracts of both skin and aorta from the patient was only $5-12 \%$ of that in comparable extracts from control subjects. In common with previous findings $(20,23)$, negligible activity was found in the initial PBS extracts of either the patient's or control tissues.

Solubility of collagen in tissues. To determine what effect the drastic reduction in lysyl oxidase activity might have on collagen cross-linking, the extractability of collagen from both skin and aorta of the patient was examined. Initial studies in which pepsin- solubilized material was analyzed by SDS-PAGE showed, somewhat surprisingly, that the ratio of cross-linked $\beta$-dimers to single $\alpha$-chain components of type I collagen appeared not to be diminished (Fig. 3). Consequently, the solubility of collagen, as represented by the hydroxyproline content of sequential extracts of the two tissues with $1 \mathrm{M} \mathrm{NaCl}, 0.5 \mathrm{M}$ acetic acid, and $8 \mathrm{M}$ urea, was examined (Table 3). Again, quite unexpectedly, the extractability of collagen was not increased in either skin or aorta from the patient, and, indeed, in the patient's aorta, actually appeared to be considerably reduced. The collagen content of

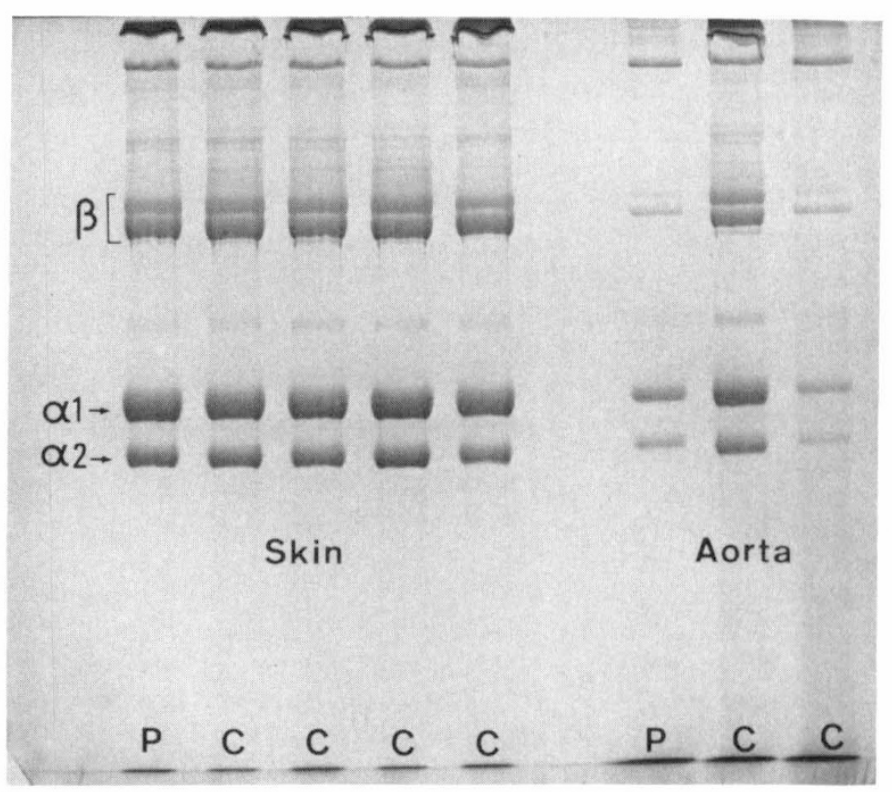

Fig. 3. SDS-PAGE analysis of pepsin-extracted collagen from tissues of the patient and controls. Collagen from skin and aorta of the patient and controls was extracted by digestion of the tissues with pepsin, and the solubilized material was analyzed by SDS-PAGE with Coomassie Brilliant Blue R.250 staining, as described in Materials and Methods. The $\beta$-components, $\beta_{11}$ (upper band) and $\beta_{12}$ (lower band), are crosslinked dimers of the constituent $\alpha 1$ and $\alpha 2$ chains of type I collagen (34). $P$, patient; $C$, controls.

Table 3. Extractability of collagen from tissues*

\begin{tabular}{lrcc}
\hline & \multicolumn{3}{c}{$\begin{array}{c}\text { Hydroxyproline }(\mu \mathrm{g} / \mathrm{mg} \text { of total } \\
\text { hydroxyproline })\end{array}$} \\
\cline { 2 - 4 } Extractable in: & Patient & Controls (mean) & Range \\
\hline Skin & \multicolumn{3}{c}{$(n=4)$} \\
$1 \mathrm{M} \mathrm{NaCl}$ & 39.7 & 40.2 & $23.0-66.5$ \\
$0.5 \mathrm{M}$ acetic acid & 157.2 & 166.6 & $107.2-231.5$ \\
$8 \mathrm{M}$ urea & 395.2 & 366.6 & $245.7-535.3$ \\
Total extractable & 592.1 & 573.4 & $430.3-766.5$ \\
Residue & 407.9 & 426.7 & $233.5-569.7$ \\
& & & \\
Aorta & & $(n=2)$ & $19.9 ; 37.5$ \\
$1 \mathrm{M} \mathrm{NaCl}$ & 27.9 & 28.7 & $29.8 ; 43.7$ \\
$0.5 \mathrm{M}$ acetic acid & 11.1 & 36.8 & $41.2 ; 52.7$ \\
$8 \mathrm{M}$ urea & 22.5 & 47.0 & $102.5 ; 122.5$ \\
Total extractable & 61.5 & 112.5 & $877.5 ; 897.5$ \\
Residue & 938.5 & 887.5 &
\end{tabular}

* After homogenization, the tissue samples were extracted sequentially with $1 \mathrm{M} \mathrm{NaCl}, 0.5 \mathrm{M}$ acetic acid, and $8 \mathrm{M}$ urea and the hydroxyproline contents of the extracts and insoluble residues were determined as described in Materials and Methods. Although the fraction of total hydroxyproline solubilized from skin (57\%) is far greater than the $3 \%$ reported by Peltonen et al. (23), this is a reflection of the difference in ages of the control subjects in the two studies, infants in the present one, and adults in the other. The proportional distribution of hydroxyproline among the different fractions is directly comparable in the two studies. 
the patient's tissues, as represented by their hydroxyproline content, was also calculated; although that of the skin might be considered to be marginally reduced in comparison with controls, that of the aorta was considerably increased (Table 4).

\section{DISCUSSION}

The connective tissue manifestations in our patient were far more extreme than is normally the case in Menkes' disease, although there have been occasional reports of cases with severe skeletal manifestations $(4,35)$. Fibroblasts from the patient displayed the characteristic copper accumulation phenotype and the copper content of both skin and aorta was elevated (in the latter tissue, doubled). Values for comparison of the copper content of tissues from Menkes' patients untreated with copper do not appear to be available in the literature. Although prenatally the copper content of extra-hepatic tissues is elevated in Menkes' disease, postnatally, with the exception of gut mucosa and kidney, it is decreased (4); it may be a reflection of the severity of the disorder in our patient that tissue copper levels remained elevated at 11 mo of age.

Presumably consequent upon the nonavailability of copper, which appears to be required for the biosynthesis of the enzyme $(36,37)$, and responsible for the connective tissue manifestations, lysyl oxidase activity in both cultured fibroblasts and extracts of skin and aorta derived from the patient was found to be drastically reduced in comparison with control values. Indeed, in cultured fibroblasts, the activity was much less than in cultures derived from two other patients with Menkes' disease, which may explain the unusual severity of the connective tissue involvement in our patient. We are unaware of any other report of levels of lysyl oxidase activity in extracts of tissues from patients with Menkes' disease, and the present results confirm that the reduction of activity previously observed in vitro $(19,23)$ is reflective of the situation in vivo. The decrease in lysyl oxidase activity occurred despite a copper accumulation phenotype in cultured fibroblasts and elevated copper levels in tissue, and provides further support for the concept of a functional intracellular copper deficiency. That the diminished lysyl oxidase activity was a genuine feature of the disease phenotype and did not result from any generalized, nonspecific effect of the disturbance in copper metabolism was indicated by the finding that the activity of prolyl hydroxylase, a ferrous ion-dependent enzyme critical in collagen biosynthesis and selected as a reference, was found to be normal. Although we feel it unlikely, the possibility of a mutation directly affecting the genes for lysyl oxidase and other copper-dependent enzymes and a cellular copper transport protein (38) cannot be absolutely excluded.

Despite the severe reduction of lysyl oxidase activity, it was noted on SDS-PAGE analysis of collagen extracted from the patient's skin and aorta that there did not appear to be any decrease in the ratio of cross-linked $\alpha$-chain dimers, the $\beta$ components, to single $\alpha$-chains, as might have been expected to have been the case, particularly since manipulation of lysyl oxidase activity by direct inhibition (39) or by dietary copper deficiency (40) has been shown previously to decrease the $\beta: \alpha$ ratio. Consequently, the solubility of collagen was examined directly by quantifying the hydroxyproline content of sequential extracts of both skin and aorta with $1 \mathrm{M} \mathrm{NaCl}, 0.5 \mathrm{M}$ acetic acid, and $8 \mathrm{M}$ urea, but it did not appear to be increased in the case of the patient. Indeed, whereas the solubility of collagen in

Table 4. Hydroxyproline content of tissues*

\begin{tabular}{lccc}
\hline & Patient & Controls & Control range \\
\hline Skin & 790 & 956 & $889-1035(n=4)$ \\
Aorta & 796 & 474 & $390 ; 558(n=2)$ \\
\hline
\end{tabular}

* Results are presented as $\mu \mathrm{g}$ of hydroxyproline/100 mg wet wt of tissue. Dry wt as a proportion of wet wt $(25-30 \%)$ was approximately equivalent in tissues from the patient and controls. the patient's skin did not differ from controls, in the aorta it actually seemed to be decreased. It is not clear why this result should conflict with the report of increased solubility of collagen in fibroblast cultures from Menkes' patients (23), but it does not appear that it can be explained by a rapid degradation of uncrosslinked material, inasmuch as there was no real alteration in the collagen content of the tissues. It may be the case, as previously suggested (19), that the major reducible intermolecular crosslinks of collagen, each of which requires the participation of only one lysyl or hydroxylysyl aldehyde precursor, are less seriously affected by severely depressed levels of lysyl oxidase activity than are those of elastin, each of which requires the participation of three appropriately positioned lysyl aldehyde precursors. Whatever the reason, the finding is in accord with ultrastructural observations suggesting a far greater disruption of fibrillar organization of elastin than of collagen (24, and Baccarani-Contri M, Pasquali-Ronchetti I, Royce PM, Steinmann B, unpublished observations). The relationship between lysyl oxidase activity and collagen solubility is not entirely clear, and findings of relevance to ours have been described in glucocorticoid-treated rats, in which, despite a significantly decreased level of lysyl oxidase activity in skin, there was an increase in the $\beta$ : $\alpha$ ratio and a decrease in the solubility of collagen (41).

The occipital horn syndrome (Ehlers-Danlos syndrome type IX; X-linked cutis laxa) (MIM 30415 in ref 1; 4, 42) is a related disorder in which a disturbance in copper metabolism with a similar copper accumulation phenotype appears to result in a comparable secondary decrease in lysyl oxidase activity as measured both in cultured fibroblasts and skin extracts $(23,43)$. It is characterized principally by connective tissue manifestations, which include mild skin laxity and hyperelasticity, bladder diverticula, recurrent inguinal hernias, mild joint hypermobility, and skeletal features of which the most apparent are occipital exostoses, with little of the neurologic involvement that is predominant in Menkes' disease $(44,45)$. In the occipital horn syndrome, the decreased lysyl oxidase activity is accompanied by an increased solubility of collagen in both fibroblast cultures and skin (23). The different biochemical and clinical findings in the two disorders with similar phenotypes resemble those observed in the mottled mouse mutants, a graded series of variants with a homologous disturbance of copper metabolism (4). Mice bearing the allele "brindled" at the Mottled locus $\left(\mathrm{Mo}^{\mathrm{br}} / \mathrm{Y}\right)$ have about half the normal level of lysyl oxidase activity in skin (27, 38 ) and die at about $14 \mathrm{~d}$ of age exhibiting signs of a neurologic disorder without evidence of any connective tissue abnormality (46), whereas the blotchy variant $\left(\mathrm{Mo}^{\text {blo }} / \mathrm{Y}\right)$ has $\sim 20-30 \%$ of normal lysyl oxidase activity in skin $(27,38)$ and dies of aortic aneurysm at 150-200 d of age (47). Allelism of the mouse mutants has generally been assumed $(4,18)$, but it may be that there are two different but closely linked X-chromosomal loci involved, with the brindled mouse being homologous to Menkes' disease, and the blotchy mouse to the occipital horn syndrome (4). The patient studied in our report seemed to combine the neurologic manifestations of Menkes' disease with the connective tissue manifestations of the occipital horn syndrome, and may reflect the genetic heterogeneity of X-linked mutations affecting copper handling.

Acknowledgments. The authors thank Dr. T. Tønnesen, of the John F. Kennedy Institute, Glostrup, Denmark, for performing the ${ }^{64} \mathrm{Cu}$ uptake studies on cultured fibroblasts, and Dr. N. Blau and M. Manser, both of the Department of Clinical Chemistry of this hospital, for their operation of the atomic absorption spectrophotometer and the amino acid analyzer, respectively We are also grateful to Prof. E. Gautier of the Centre Hospitalie Universitaire Vaudois, Lausanne, Switzerland, for bringing the patient to our attention. 


\section{REFERENCES}

1. McKusick VA 1988 Mendelian Inheritance in Man. Catalogs of Autosomal Dominant. Autosomal Recessive, and X-Linked Phenotypes, 8th Ed. Johns Hopkins University Press, Baltimore

2. Horn N 1984 Copper metabolism in Menkes' disease. In: Rennert OM, Chan W-Y (eds) Metabolism of Trace Metals in Man, Vol II, Developmental Biology and Genetic Implications. CRC Press, Boca Raton, pp 25-52

3. Baerlocher K. Nadal D 1988 Das Menkes-Syndrom. Ergeb Inn Med Kinderheilkd 57:77-144

4. Danks DM 1989 Disorders of copper transport. In: Scriver CR, Beaudet AL Sly WS, Valle D (eds) The Metabolic Basis of Inherited Disease, 6th Ed, Vol I. McGraw-Hill, New York, pp 1411-1431

5. Procopis P, Camakaris J, Danks DM 1981 A mild form of Menkes steely hair syndrome. J Pediatr 98:97-99

6. Danks DM 1988 The mild form of Menkes disease: progress report on the original case. Am J Med Genet 30:859-864

7. Westman JA, Richardson DC, Rennert OM, Morrow III G 1988 Atypical Menkes steely hair disease. Am J Med Genet 30:853-858

8. Baerlocher KE, Steinmann B, Rao VH, Gitzelmann R, Horn N 1983 Menkes' disease: clinical, therapeutic and biochemical studies. J Inherited Metab Dis 6(suppl 2):87-88

9. Gerdes A-M, Tonnesen T, Pergament E, Sander C. Baerlocher KE, Wartha R, Güttler F. Horn N 1988 Variability in clinical expression of Menkes syndrome. Eur J Pediatr 148:132-135

10. Nadal D, Baerlocher K 1988 Menkes' disease: long-term treatment with copper and D-penicillamine. Eur J Pediatr 147:621-625

11. Sander C. Niederhoff H, Horn N 1988 Life-span and Menkes kinky hair syndrome: report of a 13-year course of this disease. Clin Genet 33:228-233

12. Danks DM, Stevens BJ, Campbell PE, Gillespie JM, Walker-Smith J, Blomfield J, Turner B 1972 Menkes' kinky-hair syndrome. Lancet 1:1100-1103

13. Danks DM. Campbell PE, Stevens BJ. Mayne V. Cartwright E 1972 Menkes's kinky hair syndrome. An inherited defect in copper absorption with widespread effects. Pediatrics 50:188-201

14. Danks DM 1977 Copper transport and utilisation in Menkes' syndrome and in mottled mice. Inorg Perspect Biol Med 1:73-100

15. Goka TJ, Stevenson RE, Hefferan PM, Howell RR 1976 Menkes disease: a biochemical abnormality in cultured human fibroblasts. Proc Natl Acad Sci USA 73:604-606

16. Horn N 1976 Copper incorporation studies on cultured cells for prenatal diagnosis of Menkes' disease. Lancet 1:1156-1158

17. Camakaris J, Danks DM. Ackland L, Cartwright E, Borger P, Cotton RGH 1980 Altered copper metabolism in cultured cells from human Menkes' syndrome and mottled mouse mutants. Biochem Genet 18:117-131

18. Danks DM 1986 Of mice and men, metals and mutations. J Med Genet 23:99-106

19. Royce PM, Camakaris J. Danks DM 1980 Reduced lysyl oxidase activity in skin fibroblasts from patients with Menkes' syndrome. Biochem J 192:579586

20. Siegel RC 1979 Lysyl oxidase. Int Rev Connect Tissue Res 8:73-118

21. Eyre D 1987 Collagen cross-linking amino acids. Methods Enzymol 144:115139

22. Robins SP 1988 Functional properties of collagen and elastin. Baillieres Clin Rheumatol 2:1-36

23. Peltonen L. Kuivaniemi H, Palotie A. Horn N, Kaitila I, Kivirikko KI 1983 Alterations in copper and collagen metabolism in the Menkes syndrome and a new subtype of the Ehlers-Danlos syndrome. Biochemistry 22:6156-6163

. Oakes BW. Danks DM. Campbell PE 1976 Human copper deficiency: ultrastructural studies of the aorta and skin in a child with Menkes' syndrome, Exp Mol Pathol 25:82-98

25. Gautier E, Frenk E, Uske A, Queloz J, Laurini R 1988 Maladie de Menkes. Description d'un cas avec atteinte prononcée des tissus conjonctifs et altération des desmosomes épidermiques. Helv Paediat Acta 43:333-344

26. Stevens BJ 1972 Biological applications of the carbon rod atomizer in atomic absorption spectroscopy. 2. Determination of copper in small samples of tissue. Clin Chem 18:1379-1384

27. Royce PM, Camakaris J, Mann JR, Danks DM 1982 Copper metabolism in mottled mouse mutants. The effect of copper therapy on lysyl oxidase activity in brindled $\left(\mathrm{Mo}^{\mathrm{br}}\right)$ mice. Biochem J 202:369-371

28. Pinnell SR, Martin GR 1968 The cross-linking of collagen and elastin: enzymatic conversion of lysine in peptide linkage to $\alpha$-aminoadipic- $\delta$-semialdehyde (allysine) by an extract from bone. Proc Natl Acad Sci USA 61:708714

29. Kivirikko KI, Myllylä R 1982 Posttranslational enzymes in the biosynthesis of collagen: intracellular enzymes. Methods Enzymol 82:245-304

30. Royce PM, Steinmann B, Vogel A. Steinhorst U. Kohlschütter A 1990 Brittle cornea syndrome: an heritable connective tissue disorder distinct from Ehlers-Danlos syndrome type VI and fragilitas oculi, with spontaneous perforations of the eye, blue sclerae, red hair, and normal collagen lysyl hydroxylation. Eur J Pediatr 149:465-469

31. Steinmann B, Rao VH, Vogel A, Bruckner P, Gitzelmann R, Byers PH 1984 Cysteine in the triple-helical domain of one allelic product of the $\alpha$ I (I) gene of type I collagen produces a lethal form of osteogenesis imperfecta. J Biol Chem 259:11129-11138

32. Horn N, Mooy P, McGuire VM 1980 Menkes X-linked disease: two clonal cell populations in heterozygotes. J Med Genet 17:262-266

33. Layman DL, Narayanan AS, Martin GR 1972 The production of lysyl oxidase by human fibroblasts in culture. Arch Biochem Biophys 149:97-101

34. Bornstein P, Traub W 1979 The chemistry and biology of collagen. In: Neurath H, Hill RL (eds) The Proteins. Academic Press, New York, pp 411-632

35. Wendler H, Mutz I 1985 Menkes-Syndrom mit exzessiven Skelettveränderungen. Fortschr Geb Rontgenstr Nuklearmed Erganzungsband 143:351-355

36. Rayton JK, Harris ED 1979 Induction of lysyl oxidase with copper. Properties of an in vitro system. J Biol Chem 254:621-626

37. Kuivaniemi H, Peltonen L, Kivirikko KI 1985 Type IX Ehlers-Danlos syndrome and Menkes syndrome: the decrease in lysyl oxidase activity is associated with a corresponding deficiency of the enzyme protein. Am J Hum Genet 37:798-808

38. Rowe DW, McGoodwin EB, Martin GR, Grahn D 1977 Decreased lysyl oxidase activity in the aneurysm-prone, mottled mouse. J Biol Chem 252:939-942

39. Carnes WH 1971 Role of copper in connective tissue metabolism. Fed Proc Fed Am Soc Exp Biol 30:995-1000

40. O’Dell BL 1976 Biochemistry and physiology of copper in vertebrates. In: Prasad AS (ed) Trace Elements in Human Health and Disease, Vol I. Academic Press, New York, pp 391-413

41. Counts DF, Shull S, Cutroneo KR 1986 Skin lysyl oxidase activity is not rate limiting for collagen crosslinking in the glucocorticoid-treated rat. Connect Tissue Res 14:237-243

42. Beighton P, de Paepe A, Danks D, Finidori G, Gedde-Dahl T, Goodman R, Hall JG, Hollister DW. Horton W. McKusick VA, Opitz JM. Pope FM. Pyeritz RE, Rimoin DL. Sillence D. Spranger JW. Thompson E. Tsipouras P, Viljoen D, Winship I, Young I 1988 International nosology of heritable disorders of connective tissue, Berlin 1986. Am J Med Genet 29:581-594

43. Byers PH, Siegel RC. Holbrook KA. Narayanan AS, Bornstein P. Hall JG $1980 \mathrm{X}$-linked cutis laxa. Defective cross-link formation in collagen due to decreased lysyl oxidase activity. N Engl J Med 303:61-65

44. Hollister DW 1982 Clinical features of Ehlers-Danlos syndrome types VIII and IX. In: Akeson WH, Bornstein P, Glimcher MJ (eds) American Academy of Orthopaedic Surgeons Symposium on Heritable Disorders of Connective Tissue. CV Mosby, St. Louis, pp 102-113

45. Kaitila II, Peltonen L. Kuivaniemi H. Palotie A, Elo J, Kivirikko KI 1982 A skeletal and connective tissue disorder associated with lysyl oxidase deficiency and abnormal copper metabolism. In: Papadotos CJ, Bartsocas CS (eds) Skeletal Dysplasias. Alan R Liss, New York, pp 307-315

46. Phillips M, Camakaris J, Danks DM 1986 Comparison of copper deficiency states in the murine mutants blotchy and brindled. Changes in copperdependent enzyme activity in 13-day-old mice. Biochem J 238:177-183

47. Rowe DW, McGoodwin EB, Martin GR, Sussman MD, Grahn D, Faris B. Franzblau C 1974 A sex-linked defect in the cross-linking of collagen and elastin associated with the mottled locus in mice. J Exp Med 139:180-192 